\title{
2013s-04
}

\section{Contracting Institutions and Ownership Structure in International Joint Venture}

\author{
Ari Van Assche. Galina A. Schwartz.
}

Série Scientifique
Scientific Series

\section{Montréal}

Février 2013

(C) 2013 Ari Van Assche, Galina A. Schwart. Tous droits réservés. All rights reserved. Reproduction partielle permise avec citation du document source, incluant la notice $($.

Short sections may be quoted without explicit permission, if full credit, including (C) notice, is given to the source.
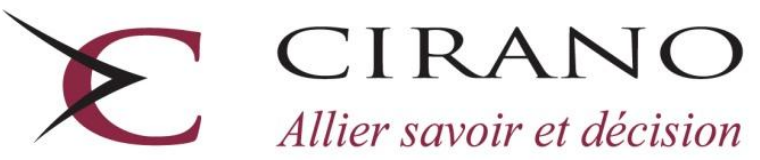

Allier savoir et décision

Centre interuniversitaire de recherche en analyse des organisations 


\section{CIRANO}

Le CIRANO est un organisme sans but lucratif constitué en vertu de la Loi des compagnies du Québec. Le financement de son infrastructure et de ses activités de recherche provient des cotisations de ses organisations-membres, d'une subvention d'infrastructure du Ministère du Développement économique et régional et de la Recherche, de même que des subventions et mandats obtenus par ses équipes de recherche.

CIRANO is a private non-profit organization incorporated under the Québec Companies Act. Its infrastructure and research activities are funded through fees paid by member organizations, an infrastructure grant from the Ministère du Développement économique et régional et de la Recherche, and grants and research mandates obtained by its research teams.

\section{Les partenaires du CIRANO}

\section{Partenaire majeur}

Ministère de l'Enseignement supérieur, de la Recherche, de la Science et de la Technologie

Partenaires corporatifs

Autorité des marchés financiers

Banque de développement du Canada

Banque du Canada

Banque Laurentienne du Canada

Banque Nationale du Canada

Banque Scotia

Bell Canada

BMO Groupe financier

Caisse de dépôt et placement du Québec

Fédération des caisses Desjardins du Québec

Financière Sun Life, Québec

Gaz Métro

Hydro-Québec

Industrie Canada

Investissements PSP

Ministère des Finances du Québec

Power Corporation du Canada

Rio Tinto Alcan

State Street Global Advisors

Transat A.T.

Ville de Montréal

\section{Partenaires universitaires}

École Polytechnique de Montréal

HEC Montréal

McGill University

Université Concordia

Université de Montréal

Université de Sherbrooke

Université du Québec

Université du Québec à Montréal

Université Laval

Le CIRANO collabore avec de nombreux centres et chaires de recherche universitaires dont on peut consulter la liste sur son site web.

Les cahiers de la série scientifique (CS) visent à rendre accessibles des résultats de recherche effectuée au CIRANO afin de susciter échanges et commentaires. Ces cahiers sont écrits dans le style des publications scientifiques. Les idées et les opinions émises sont sous l'unique responsabilité des auteurs et ne représentent pas nécessairement les positions du CIRANO ou de ses partenaires.

This paper presents research carried out at CIRANO and aims at encouraging discussion and comment. The observations and viewpoints expressed are the sole responsibility of the authors. They do not necessarily represent positions of CIRANO or its partners. 


\title{
Contracting Institutions and Ownership Structure in International Joint Ventures
}

\author{
Ari Van Assche ${ }^{\dagger}$, Galina A. Schwartz
}

\section{Résumé / Abstract}

This paper examines the role of contracting institutions on a multinational firm's optimal ownership strategy. We develop a model in which both a multinational firm and its local joint venture partner can ex post engage in costly rent-seeking actions to increase their ex ante agreed upon revenue share. We show that the host country's level of contract enforcement and level of judicial favoritism affect the parties' incentives to contribute to the international joint venture. The model allows us to identify testable hypotheses relating these institutional features with the performance and optimal ownership structure of international joint ventures.

\begin{abstract}
Mots clés : international joint venture, ownership structure, institutions, contract enforcement, judicial favoritism.
\end{abstract}

Codes JEL : F23, L14, L24.

\footnotetext{
* We thank editor Eric Verhoogen, two anonymous reviewers, and seminar participants at the Université de Québec à Montréal, Carleton University, the Katholieke Universiteit Leuven, George Washington University and the University of Hawaii at Manoa for helpful comments and suggestions. Van Assche thanks the fonds québécois de la recherche sur la société et la culture (FQRSC) for financial support. Schwartz thanks the financial support of TRUST (Team for Research in Ubiquitous Secure Technology), which receives support from the National Science Foundation (\#CCF-0424422) and the following organizations: AFOSR (\#FA9550-06-10244), BT, Cisco, DoCoMo USA Labs, EADS, ESCHER, HP, IBM, iCAST, Intel, Microsoft, ORNL, Pirelli, Qualcomm, Sun, Symantec,TCS, Telecom Italia, and United Technologies.

${ }^{\dagger}$ Corresponding author. HEC Montréal, 3000 Chemin de la Côte-Sainte-Catherine, Montréal (QC), Canada H3T 2A7. Phone: (514)340-6043. Fax: (514)340-6987. E-mail: ari.van-assche@ hec.ca.

${ }^{\ddagger}$ University of California-Berkeley.
} 


\section{Introduction}

Many multinational enteprises (MNEs) have been struggling to successfully operate in developing countries (Cuervo-Cazurra et al., 2007; Khanna et al., 2005). A main stumbling block is their difficulties to adapt to the unfamiliar institutional environments. Compared to developed countries, both the "contracting institutions", which enable contracts between citizens, and the "property rights institutions", which protect citizens against expropriation, are generally weaker (Acemoglu and Johnson, 2005), thus altering the rules of the game. ${ }^{1}$ As a consequence, the strategies that MNEs have successfully adopted at home are not easily transferable to their operations in developing countries.

A sizeable literature in economics and business has investigated how MNEs should adapt their entry mode choice to cope with institutional differences. One set of studies suggests that a MNE should form and international joint venture (IJV) with a local firm in developing countries to leverage its local partner's comparative advantage in navigating local institutions (Inkpen and Beamish, 1997; Luo, 2002; Meyer et al., 2009) and to mitigate the risk of government expropriation (Hennart, 1988). Other papers counter that forming an IJV also increases contractual hazards, thus reducing the value of partnering with a local firm (Javorcik and Wei, 2009; Henisz, 2000; Henisz and Williamson, 1999). These studies therefore recommend that MNEs with important intangible assets (e.g., intellectual property) should enter as a wholly-owned subsidiary in markets with underdeveloped contracting institutions.

An issue that has received less attention is whether MNEs should adjust their contracts with local partners when operating in developing countries. There are both theoretical and empirical reasons why this could be an important strategic tool to cope with underdeveloped institutions. First, recent theoretical studies show that contracting parties can deal with predictable biases in the judicial system by distorting the form of their contracts (Bond, 2009; Gennaioli, 2012; Gennaioli and Perotti, 2012). Furthermore, a number of empirical papers find that the contractually defined governance structure of an IJV has a distinct impact on its performance in developing countries. This includes Beamish (1985) and Beamish and Choi (2004) who find that IJVs with shared

\footnotetext{
${ }^{1}$ North (1990) defines institutions as "the rules of the game in a society or, more formally, [...] the humanly devised constraints that shape human interaction.
} 
management arrangements perform better than dominant parent arrangements in many developing countries. Similarly, Steensma and Lyles (2000) show that, unlike in developed countries, an imbalance in ownership between IJV partners reduces the likelihood of a joint venture's survival. Since IJVs continue to make up a substantial proportion of foreign investment in developing countries (Beamish and Lupton, 2009), these findings call for a better understanding of the link between institutions and the form of an IJV contract.

In this paper, we aim to gain new insights into this issue by investigating how contracting institutions affect the optimal ownership structure in IJVs. We focus on two characteristics of contracting institutions: contract enforcement and judicial favoritism. First, contract enforcement is lower in countries with weaker judicial systems. Courts in such countries often have limited capabilities of verifying contractual contingencies due to lack of their judges' competencies and due to their need to base their rulings on an underdeveloped body of laws and regulations (Acemoglu et al., 2007; Hay et al., 1996). Furthermore, with courts less accountable for the quality of their judgements, judges often have the power to alter their rulings in line with their own idiosyncratic views (Gennaioli, 2012) or in favor of the party that pays the highest bribe (Bond, 2009; Glaeser and Schleifer, 2002). With contracts less likely to be enforced, contracting parties have a heightened incentive to ex post violate the terms of the original contract, therefore distorting contracting parties' incentives to contribute relationship-specific investments to the IJV. Second, judicial favoritism towards local firms is more prevalent in countries with weaker judicial systems. If contract enforcement is weak and cronyism is rampant, courts are prone to systematically favor their own nationals at the expense of foreigners, therefore disproportionately weakening the MNE's incentives to contribute to the IJV (Mui, 1999).

To study the impact of contract enforcement and judicial favoritism on the ownership structure of an IJV, we embed a simple rent-seeking contest in a standard joint venture model. A MNE first (ex ante) signs a linear revenue-sharing contract with a local partner. Then each party contributes specialized inputs to create joint revenue. Finally (ex post), both parties enter a rent-seeking contest where they can take costly private actions to increase their own share of the IJV revenue. A country's institutional environment is reflected in the parties' costs of taking these rent-seeking actions. If the cost of rent-seeking actions is high for both IJV parties, they have a low incentive to 
violate the stipulations of the original contract. In our model, we thus capture the level of contract enforcement with the cost of ex post taking rent-seeking actions. Furthermore, we capture the level of judicial favoritism in the host country by assuming that the cost of rent-seeking actions may be larger for the MNE than for its local partner. The higher the cost advantage of the local partner, the larger the court's judicial favoritism towards local firms. While our approach of modeling contracting institutions is stylized, it permits us to analyze the impact of two key characteristics of contracting institutions on the optimal ownership structure in IJVs in a transparent fashion.

The key results of our model are as follows. Weaker contract enforcement negatively affects the IJV's performance by inducing both parties to waste resources on rent-seeking activities and by weakening their incentives to contribute inputs to the IJV. Interestingly, we find that parties' incentives to contribute inputs are asymmetrically affected by a change in the degree of contract enforcement. Specifically, weaker contract enforcement disproportionately lowers the incentives of the minority partner in the IJV, i.e. the party that contributes relatively less. Our model finds that is therefore optimal to allocate a larger ownership share to the minority partner, moving the IJV closer to a 50-50 ownership distribution.

This result is in line with the observed clustering around 50-50 equity allocations in many international joint ventures operating in developing countries (Bai et al., 2004; Moskalev and Swensen, 2007). Our theoretical explanation for this phenomenon, however, is fundamentally different from previous studies. The established argument has been that IJV parties adopt 50-50 ownership to prevent the majority partner from using its control rights to extract rents from the minority partner (Bai et al., 2004; Hauswald and Hege, 2009; Wang and Zhu, 2005). In our model, 50-50 ownership clustering also neutralizes the majority partner's power to expropriate rents from the minority partner, but the source of power is driven by the institutional environment and not by control rights.

Judicial favoritism also distorts incentives asymmetrically, but in a different way. In our model, it allows the local partner to ex post appropriate a portion of the MNE's revenue share, therefore weakening the MNE's incentives to contribute inputs to the IJV while strengthening the incentives of the local partner. This leads to three results. First, to neutralize this incentive distortion in the IJV, we find that it is optimal to allocate a higher ownership share to the MNE. Second, as 
long as the IJV can successfully increase the MNE's ownership share to the optimal level, judicial favoritism does not reduce the performance of the IJV. Third, the requirement to allocate a higher ownership share to the MNE renders certain types of IJVs unfeasible. Especially for IJVs in which the MNE contributes relatively more, setting up an IJV no longer is a feasible entry strategy.

Our paper relates to several literatures in contract theory and international trade. As already mentioned, from the point of view of contract theory, the closest studies investigate how parties distort their contracts to deal with predictable biases in a country's legal system. It includes the work of Bond (2009) who shows that judicial corruption can refrain contracting parties from employing high-powered contracts. In a similar spirit, Gennaioli (2012) illustrates that potential judicial biases can induce contracting parties to adopt less flexible non-contingent financial contracts. And Gennaioli and Perotti (2012) show that an environment with unequal litigation ability between parties can lead to the adoption of standardized contracts that are contingent on only few, preset pieces of evidence. Our contribution relative to these studies is that we focus on ownership structure as a strategic tool to cope with institutions. Furthermore, we apply our model in a tractable way to the context of IJVs.

Our paper is also related to a trade literature that emphasizes the role of contracting institutions on the organizational form of MNEs. This includes the work of Acemoglu et al. (2007) and Antràs and Helpman (2008). Our approach differs from these papers in the way that contracting institutions are modeled. While these studies proxy the quality of a judicial system with the fraction of tasks that are contractible, we model it with the cost for parties to ex post take rent-seeking actions. Our alternative approach allows us to identify new channels through which contracting institutions affect the optimal organizational form of MNEs.

The rest of the paper is organized as follows. In Section 2, we set up the IJV model. In Section 3 , we solve the model in the benchmark environment with perfect contract enforcement. In Section 4 and 5, we study the effects of contract enforcement and judicial favoritism, respectively, on the performance and ownership structure of the IJV. Section 6 discusses the results of the model and Section 7 concludes. 


\section{IJV Model}

Consider a multinational firm $M$ that sets up an IJV with a local firm $D$. Let the IJV face an iso-elastic inverse demand function for its output $y:^{2}$

$$
p=\lambda^{1-\alpha} y^{-(1-\alpha)},
$$

where $p$ denotes price, $1 /(1-\alpha)$ is the elasticity of demand, and $\lambda>0$ is a demand shifter that the IJV treats as exogenous. ${ }^{3}$

Production of final good $y$ requires two complementary inputs: foreign inputs $m$ produced by the MNE at unit cost $\rho$ and local inputs $d$ produced by the local firm at unit cost $\omega$. We assume that the inputs are relationship-specific, that is, they have zero outside value if the IJV relationship breaks down. In order to parameterize the value of each partners contribution to the joint venture, we assume the IJV produces final good $y$ from inputs $m$ and $d$ via a Cobb-Douglas production function:

$$
y=\left(\frac{m}{\eta}\right)^{\eta}\left(\frac{d}{1-\eta}\right)^{1-\eta}
$$

where $\eta \in[0,1]$ is a parameter characterizing the intensity of foreign inputs in production. By combining (1) and (2), the IJV's revenue can be expressed as

$$
R(m, d)=\lambda^{1-\alpha}\left(\frac{m}{\eta}\right)^{\alpha \eta}\left(\frac{d}{1-\eta}\right)^{\alpha(1-\eta)}
$$

We assume that revenue $R$ is verifiable by an outside party, but that the quality of inputs is unverifiable. To induce the IJV partners to provide the required specific inputs, they can sign a linear revenue-sharing contract that links their incomes to the verifiable joint revenue. ${ }^{4}$ Specifically,

\footnotetext{
${ }^{2}$ It is well established that this inverse demand function can be derived from a setting in which a representative consumer's preferences across varieties has a constant elasticity of substitution: $U=\left(\int_{i \in \Phi} y(i)^{\alpha} d i\right)^{\frac{1}{\alpha}}$, where $\Phi$ is the set of available varieties.

${ }^{3}$ We assume that $\alpha \in[0,1 / 2]$ to guarantee the uniqueness of an equilibrium in section 4 . See Appendix for more details.

${ }^{4}$ Such linear contracts are widespread in business practices due to their their simplicity and transparency (Bhattacharyya and Lafontaine, 1995). They are also widely adopted by the literature on joint ventures, see Bai et al. (2004) and Wang and Zhu (2005).
} 
the MNE can propose a take-it-or-leave-it IJV contract to a local firm that specifies (i) the MNE's ownership share $s \in[0,1]$ that gives it right to revenue share $s$ and (ii) a fixed lump-sum payment $t$ between the two parties that takes place ex ante, i.e. prior to the production of inputs.

A particular feature of our model is that IJV partners can ex post take rent-seeking actions to increase their ex ante determined allocation of revenue. After parties have produced their inputs and revenue is realized, each party $i \in\{M, D\}$ can take private actions to increase its revenue share by $r_{i}$. Let $v$ and $1-v$ denote the ex post revenue share for the MNE and local firm respectively. Parties ex post choose $r_{m}$ and $r_{d}$ so that the MNE's ex post revenue share

$$
v=s+r_{m}-r_{d}
$$

Ex post rent-seeking actions are costly to conceal from local courts. Parties need to spend resources to persuade the local court that the rent-seeking actions do not violate the terms of the contract. They can do so by creating litigation arguments (Gennaioli and Perotti, 2012) or, less legally, by bribing court officials (Bond, 2009). We assume that both parties have equal litigation and bribing abilities. $^{5}$ Furthermore, since larger deviations from the original contract are harder to conceal, rent-seeking costs become plausibly higher the larger is the revenue share that they grab from the other party. We capture this conveniently in terms of a convex cost function $B\left(r_{i}\right)$ that is increasing in the amount of revenue share, $r_{i}$, that party $i$ takes from its IJV partner: ${ }^{6}$

$$
B\left(r_{i}\right)=\left\{\begin{array}{cl}
e^{\frac{r_{i}}{\gamma_{i}}} & \text { if } r_{i}>0 \\
0 & r_{i}=0
\end{array}\right.
$$

A key parameter in the rent-seeking cost function is $\gamma_{i}>0$, which reflects a party $i$ 's cost of concealing its rent-seeking actions. The higher $\gamma_{i}$, the lower the amount $B$ that party $i$ needs to spend to increase its revenue share by $r_{i}$. We can use the IJV parties' parameters $\gamma_{i}$ to capture two key characteristics of a host country's contracting institutions: (i) contract enforcement and

\footnotetext{
${ }^{5}$ This assumption implies that any difference in rent-seeking costs between parties is due to judicial favoritism.

${ }^{6}$ We adopt an exponential rent-seeking cost function to make the results more tractable. The cost function implies that a party has to pay a fixed cost of 1 to take rent-seeking action. This assumption can easily be generalized to account for a fixed cost of any size, without affecting the central results of the model.
} 
(ii) judicial favoritism. To structure our analysis with little loss of generality, assume that:

$$
\gamma_{d}=\gamma+\delta \text { and } \gamma_{m}=\gamma-\delta
$$

where $\gamma>\delta \geq 0$. In that case, we can use $\gamma$ as an inverse measure of contract enforcement in the host country. ${ }^{7}$ The intuition behind this is the following. If $\gamma$ rises, it becomes cheaper for both parties to ex post violate the terms of the ex ante contract, therefore weakening parties' incentives to adhere to the contract. Higher $\gamma$ thus corresponds to an environment with lower contract enforcement.

We can capture the degree of judicial favoritism in a country with the parameter $\delta$. To see this, suppose that $\delta>0$. In that case, for a given level of contract enforcement (captured by the inverse of $\gamma$ ), the cost of ex post rent-seeking actions is lower for the local firm than for the MNE. This corresponds to an environment in which the local court gives preferential treatment to local firms compared to MNEs.

The IJV model can be summarized by the following sequence of events. In period 1, the MNE offers a take-it-or-leave-it IJV contract $(s, t)$ to a local firm that specifies the MNE's ownership share $s$ and a lump-sum transfer $t$. In period 2, both parties produce their inputs $m$ and $d$. In period 3 , both parties can adjust the ex ante contract through costly actions $r_{m}$ and $r_{d}$. Below, we solve for the optimal IJV contract through backward induction. We solve the model in three steps. In Section 3, we analyze the benchmark case of perfect contract enforcement where it is too costly for parties to conduct ex post actions. In Section 4, we study the case of imperfect contract enforcement without judicial favoritism to analyze the impact of contract enforcement on the optimal IJV contract and performance. In Section 5, we analyze the case of imperfect contract enforcement with judicial favoritism to assess the additional impact of favoritism on the optimal IJV contract and performance.

\footnotetext{
${ }^{7}$ From (6), it is straightforward to show that $\gamma$ equals the average of both parties' cost parameters: $\gamma=\frac{\gamma_{m}+\gamma_{d}}{2}$.
} 


\section{Perfect Contract Enforcement}

Consider the benchmark case of perfect contract enforcement where $\gamma_{i}$ approaches 0. For both parties, the marginal cost of ex post conduct rent-seeking actions then exceeds its marginal benefit. As a result, it is optimal for each party $i$ in period 3 to choose

$$
\hat{r}_{i}=0,
$$

where the superscript`denotes optimum under perfect contract enforcement. Both parties’ ex post revenue shares then coincide with their ownership share:

$$
\hat{v}=s
$$

Next, consider the parties' choices in period 2. Here they choose profit-maximizing inputs $m$ and $d$ for a given contract $(s, t)$ :

$$
\begin{gathered}
\max _{m} \pi_{m}=s R(m, d)-\rho m+t, \\
\max _{d} \pi_{d}=(1-s) R(m, d)-\omega d-t,
\end{gathered}
$$

where $\pi_{i}$ denotes party $i$ 's profits. By solving these problems and inserting them into (3), we can express revenue $R$ as a function of the MNE's ownership share $s$ :

$$
R(s)=\lambda\left[\alpha\left(\frac{s}{\rho}\right)^{\eta}\left(\frac{1-s}{\omega}\right)^{1-\eta}\right]^{\frac{\alpha}{1-\alpha}}
$$

In period 1, the MNE offers a take-it-or-leave-it contract $(s, t)$ to its local partner that guarantees the local partner's participation in the IJV. If we normalize the local partner's ex ante outside option to zero, the multinational firm's profit maximization problem reduces to:

$$
\max _{s, t} \pi_{m}=s R(s)-\rho m(s)+t
$$


subject to

$$
\pi_{d}=(1-s) R(s)-\omega d(s)-t \geq 0 .
$$

By solving for the optimal contract $(s, t)$, we derive an expression for a MNE's optimal ownership share: ${ }^{8}$

$$
\hat{s}=\left\{\begin{array}{cc}
1 / 2 & \text { if } \eta=1 / 2 \\
\frac{\eta-\Psi}{2 \eta-1} & \text { if } \eta \neq 1 / 2
\end{array}\right.
$$

where

$$
\Psi=\alpha \eta(1-\eta)+\sqrt{\eta(1-\eta)(1-\alpha \eta)(1-\alpha+\alpha \eta)} .
$$

It is straightforward to show that $\Psi \in[0,1 / 2]$ and that $\Psi<\eta$ if $\eta<1 / 2$, while $\Psi>\eta$ if $\eta>1 / 2$. As a result, $\hat{s} \in[0,1]$.

\section{[Figure 1 about here]}

In Figure 1, we use (8) and (9) to plot as a solid curve the relation between ownership share $\hat{s}$ and the intensity of foreign inputs $\eta$. Ownership share $\hat{s}$ approaches zero when $\eta$ approaches 0 , it approaches 1 when $\eta$ approaches 1 , and it rises in between. Moreover, $\hat{s}$ is concave for $\eta<1 / 2$ and convex for $\eta>1 / 2$. These properties reflect that parties cannot contract upon the purchase of specialized inputs for a certain price. As a result, neither party appropriates the full marginal return to its investments in the supply of inputs, thus leading to underinvestment. Each party's incentives are then determined by its ownership share $s$. Ex ante efficiency thus requires giving a larger ownership share to the party undertaking the relatively more important investment into the IJV. As a result, the higher the intensity of foreign inputs (the larger $\eta$ is), the higher the MNE's ownership share $\hat{s}$ is.

Next, we can derive $\hat{\pi}_{m}$ by inserting the optimal contract $(\hat{s}, \hat{t})$ into $(7)$. This gives us

$$
\hat{\pi}_{m}=\lambda \Omega,
$$

\footnotetext{
${ }^{8}$ Notice that given the existence of ex-ante lump-sum transfers, the multinational firm will choose the ownership structure that maximizes the joint profit of $M$ and $D$, given their respective participation constraints.
} 
where

$$
\Omega=\frac{(1-\alpha(1-\Psi))}{\left(\frac{2 \eta-1}{\alpha}\left(\frac{\rho}{\eta-\Psi}\right)^{\eta}\left(\frac{\omega}{\eta+\Psi-1}\right)^{1-\eta}\right)^{\frac{\alpha}{1-\alpha}}} .
$$

In the next sections, we will use equations (10) and (11) as a benchmark to analyze the impact of the institutional features contract enforcement and judicial favoritism on the performance of an IJV.

\section{Imperfect Contract Enforcement}

Next, consider the case of imperfect contract enforcement $(\gamma>0)$ without judicial favoritism $(\delta=0)$. First, we derive parties' optimal ex post rent-seeking actions for a given $(s, t, m, d)$. In period 3, each party chooses the optimal amount $r_{i}$ that solves:

$$
\begin{gathered}
\max _{r_{m}} \pi_{m}=\left(s-r_{d}+r_{m}\right) R-B\left(r_{m}\right)-\rho m+t \\
\max _{r_{d}} \pi_{d}=\left(1-s+r_{d}-r_{m}\right) R-B\left(r_{d}\right)-\omega d-t,
\end{gathered}
$$

where the cost function $B\left(r_{i}\right)$ is given by (5) and $R$ is short for $R=R(s, t, m, d)$. The solutions of these problems yield

$$
r_{i}^{*}=\gamma \ln (\gamma R)
$$

where superscript * reflects optimum under imperfect contract enforcement. Inserting (14) into (5) then determines parties' rent-seeking expenditures

$$
B\left(r_{i}^{*}\right)=\gamma R
$$

This suggests that both parties ex post spend the equal amount fraction $\gamma$ of the IJV's revenue $R$ on rent-seeking actions to increase their revenue share with $r_{i}^{*} \cdot{ }^{9}$ Since $r_{i}^{*}$ is identical for both parties, their effects on $v$ cancel each other out. Thus, each party's ex post revenue share is identical to its

\footnotetext{
${ }^{9}$ Note that the IJV becomes unfeasible if $\gamma \geq \frac{1}{2}$. In that case, for at least one of both parties, the share of revenue $\gamma$ that it needs to pay for its rent-seeking actions exceeds its ownership share. In our discussion below, we assume that $\gamma \leq \frac{1}{2}$.
} 
ownership share:

$$
v^{*}=s
$$

In period 2, parties choose inputs $m$ and $d$ for a given $(s, t)$. By inserting (15) into (12) and (13), their maximization problems reduce to:

$$
\begin{gathered}
\max _{m} \pi_{m}=(s-\gamma) R(m, d)-\rho m+t \\
\max _{d} \pi_{d}=(1-s-\gamma) R(m, d)-\omega d-t .
\end{gathered}
$$

By solving these problems and inserting them into (3), we can derive revenue as a function of $s$ :

$$
R^{*}(s)=\lambda\left[\alpha\left(\frac{s-\gamma}{\rho}\right)^{\eta}\left(\frac{1-s-\gamma}{\omega}\right)^{1-\eta}\right]^{\frac{\alpha}{1-\alpha}}
$$

It is straightforward to show from (16) that $R^{*}$ decreases with $\gamma$. The reason is that imperfect contract enforcement negatively affects both parties' incentives to produce inputs. When choosing their optimal amount of inputs, each party takes into account that, ceteris paribus, producing more inputs increases revenue and thus raises the expenditure $\gamma R$. This acts as a disincentive for parties to produce inputs, thus magnifying the hold-up problem.

A new finding that comes out of the model is that contract enforcement affects parties' incentives to contribute inputs asymmetrically. While an increase in revenue induces both parties to increase their ex post expenditures equally, the ex post distribution of the extra revenue is not necessarily even. Specifically, the MNE ex post receives share $s$ of the extra revenue, while the local firm receives share $1-s$. We infer from this that the incentives of the minority partner in an IJV (i.e., the partner with a smaller ownership share) are affected more negatively by imperfect contract enforcement than those of the majority partner. Below, we show that this distortion of incentives affects the optimal ownership structure.

In period 1, the MNE offers a take-it-or-leave-it contract $(s, t)$ to the local firm that solves the problem

$$
\max _{s, t} \pi_{m}=(s-\gamma) R^{*}(s)-\rho m^{*}(s)+t
$$


subject to

$$
\pi_{d}=(1-s-\gamma) R^{*}(s)-\omega d^{*}(s)-t \geq 0
$$

By combining the solution of this problem with (8) and (9), we can relate the MNE's ownership share $s^{*}$ with its ownership share under perfect contract enforcement $\hat{s}$ :

$$
s^{*}=\hat{s}-\gamma \frac{1-2 \Psi}{2 \eta-1} .
$$

In Figure 1, we use (18) to plot the relation between ownership share $s^{*}$ and the intensity of foreign inputs $\eta$ as a dashed line. Similar to the benchmark case, $s^{*}$ increases with $\eta \cdot{ }^{10}$ Contract enforcement affects the intersect and slope of the curve however. First, to ensure that both parties receive a sufficiently large share of revenue to pay the expenditure $\gamma R, s^{*}$ approaches $\gamma$ when $\eta$ approaches 0 and $s^{*}$ approaches $1-\gamma$ when $\eta$ approaches 1 . Second, a comparison of (8) with (18) shows that the slope of $s^{*}$ is less steep than the slope of $\hat{s}$ and that the steepness of $s^{*}$ is positively related to contract enforcement $1 / \gamma$. This allows us to infer the following proposition:

Proposition 1 When the MNE contributes relatively more to the IJV $(\eta>1 / 2)$, its ownership share decreases with $\gamma$. Otherwise $(\eta<1 / 2)$, its ownership share increases with $\gamma$.

The intuition behind proposition 1 is the following. As we have discussed above, lower contract enforcement disproportionately weakens the incentives of the minority partner in the IJV. Since the MNE is the minority partner in a local-input intensive IJV $(\eta<1 / 2)$, it is therefore optimal to allocate a larger ownership share to the MNE to improve its incentives. In a foreign-input intensive IJV $(\eta>1 / 2)$, the local firm is the minority partner. In this case, it is optimal to allocate a larger ownership share to the local partner to strengthen its incentives.

Next, we analyze the effect of contract enforcement on the performance of an IJV. By inserting the optimal contract $\left(s^{*}, t^{*}\right)$ into (17) and combining it with (10) and (11), we obtain:

$$
\pi_{m}^{*}=\lambda \Omega(1-2 \gamma)^{\frac{1}{1-\alpha}}=\hat{\pi}_{m}(1-2 \gamma)^{\frac{1}{1-\alpha}}
$$

\footnotetext{
${ }^{10}$ Since $\Psi \leq \frac{1}{2}$ and $\frac{1}{2} \geq \gamma \geq \frac{1}{R}, \hat{s}>s^{*} \geq 0$ in local-input intensive industries $(\eta<1 / 2)$ and $1 \geq s^{*}>\hat{s}$ in foreign-input intensive industries $(\eta>1 / 2)$.
} 
Equation (19) suggests that a MNE only receives share $(1-2 \gamma)^{\frac{1}{1-\alpha}}$ of the profits it would have received under perfect contract enforcement. This share increases with contract enforcement in the host country (decreases in $\gamma$ ), thus allowing us to state the following proposition:

Proposition 2 The IJV's performance is positively related to the degree of contract enforcement (decreases with $\gamma)$.

From our discussion, lower contract enforcement reduces IJV performance through two channels. First, it magnifies the hold-up problem by reducing parties' incentives to contribute inputs to the IJV, thus reducing joint revenue. Second, it increases the amount of resources that both parties waste on their ex post rent-seeking actions. Interestingly, the loss in IJV performance is not affected by foreign input specificity $\eta$. This observation together with proposition 1 suggests that an IJV in an industry with a low or high foreign input intensity $\eta$ can be equally efficient as an IJV with an intermediate value of $\eta$ as long as the ownership structure is sufficiently adjusted to provide the minority partner with stronger incentives.

Note that the elasticity of demand $1 /(1-\alpha)$ magnifies the effect of contractual frictions on IJV performance. According to equation (19), for a given level of contract enforcement $1 / \gamma$, an IJV with a higher elasticity of demand obtains a lower share of the profits it would have received under perfect contract enforcement. We state this as corollary 1 .

Corollary 1 The negative effect of contractual frictions on an IJV's performance is magnified by an increase in the elasticity of demand $1 /(1-\alpha)$.

The intuition behind corollary 1 is the following. When IJV parties take ex post rent-seeking actions, it increases the IJV's production costs and therefore the price of its products. When the elasticity of demand is higher, this leads to a disproportionate drop in the demand for the IJV's products, therefore magnifying the negative performance effect of contractual frictions.

\section{Judicial favoritism}

Finally, we consider the case of judicial favoritism. Let $\delta>0$ so that, for a given level of contract enforcement (measured by the inverse of $\gamma$ ), the cost of ex post rent-seeking actions are higher 
for the MNE than for its local partner. In period 3, both parties choose optimal $r_{i}$ for a given $(s, t, m, d)$. Solving (12) and (13) yields:

$$
\begin{aligned}
& r_{m}^{\circledast}=(\gamma-\delta) \ln ((\gamma-\delta) R) \\
& r_{d}^{\circledast}=(\gamma+\delta) \ln ((\gamma+\delta) R)
\end{aligned}
$$

where subscript $\circledast$ reflects optimum in an environment with judicial favoritism. Combining (20) and (21) with (4) gives

$$
v^{\circledast}=s-\Delta
$$

where

$$
\Delta=r_{d}^{\circledast}-r_{m}^{\circledast} \geq 0 \text { and } \Delta=\Delta(R) .
$$

We infer from (22) and (23) that judicial favoritism allows the local partner to ex post appropriate revenue share $\Delta$ from the MNE. It is straightforward to derive that $\Delta$ increases with $R$. Specifically, if $R$ is higher, the domestic firm ex post grabs a larger share of the IJV revenue. As we demonstrate below, this implies that judicial favoritism alters parties' incentives to contribute inputs to the IJV since it affects the revenue share that the local partner is able to ex post appropriate from the MNE.

In period 2, parties choose the inputs $m$ and $d$ for a given $(s, t)$. We use equations (20)-(23) to rewrite parties' maximization problems as:

$$
\begin{gathered}
\max _{m} \pi_{m}=(s-\Delta(R(m, d))-\gamma+\delta) R(m, d)-\rho m+t \\
\max _{d} \pi_{d}=(1-s+\Delta(R(m, d))-\gamma-\delta) R(m, d)-\omega d-t .
\end{gathered}
$$

From (22)-(25), judicial favoritism affects parties' incentives to produce inputs, albeit differently. It weakens the MNE's incentives to produce inputs since the MNE considers that, ceteris paribus, producing more $m$ increases $R$ and thus increases the share $\Delta$ that the local partner appropriates from the MNE. Conversely, judicial favoritism strengthens the local firm's incentives since producing more inputs $d$ increases $R$ and thus raises the share $\Delta$ that it appropriates from the MNE. 
In period 1 , the MNE offers a take-it-or-leave-it contract $(s, t)$ to its local partner. In appendix A.1, we derive that it is optimal for a MNE to choose ownership share $s^{\circledast}$ that allows it to obtain ex post revenue share $v^{\circledast}$ :

$$
v^{\circledast}=\hat{s}-\gamma \frac{1-2 \psi}{2 \eta-1}+\delta
$$

We also demonstrate that there is a unique $s^{\circledast}$ that corresponds to $v^{\circledast}$.

If we compare $(26)$ with $(18), v^{\circledast}$ consists of three terms. The first term is the MNE's optimal ownership share under perfect contract enforcement $\hat{s}$; the second term reflects the effect of imperfect contract enforcement; and the third term reflects the effect of judicial favoritism. As is clear from (26) and as is depicted with a dashed and pointed line in Figure 1, a MNE thus should respond to an environment with judicial favoritism $(\delta>0)$ by ensuring that its ex post revenue share increases with $\delta$. As we have explained above, this is because judicial favoritism weakens the MNE's incentives to contribute inputs, while it strengthens the local firm's incentives to contribute inputs. Ensuring that the MNE's ex post revenue share increases with $\delta$ thus allows the IJV to increase the relative power of the MNE's incentives.

To obtain $v^{\circledast}$, a MNE needs to choose ownership share $s^{\circledast}$. By combining (22) with (23) and (26), it is straightforward to show that, ceteris paribus, the MNE's ownership share is larger in an environment with judicial favoritism than in an environment without judicial favoritism:

$$
s^{\circledast} \geq s^{*}=\hat{s}-\gamma \frac{1-2 \psi}{2 \eta-1} .
$$

We state this in the following proposition:

Proposition 3 Ceteris paribus, a MNE's ownership share in an IJV is higher in an environment with judicial favoritism $(\delta>0)$ than in an environment without judicial favoritism $(\delta=0)$.

Note that the MNE cannot always obtain $v^{\circledast}$ through its choice of $s^{\circledast}$. Specifically, if $v^{\circledast}+\Delta>1$, it is required to choose $s^{\circledast}>1$, which is not possible. In this case, it is profit-maximizing to choose $s^{\circledast}=1$. But this exclusive ownership goes against the notion of a joint venture. We infer that judicial favoritism negatively affects the feasibility of forming an IJV. Especially IJVs with a higher foreign-input intensity $\eta$ are likely to become unfeasible since this type of joint venture requires a 
higher $v^{\circledast}$, thus increasing the likelihood that $s^{\circledast}=1$. We state this in the following proposition:

Proposition 4 Ceteris paribus, judicial favoritism reduces the feasibility of an IJV. Feasibility is especially reduced when $\eta$ is high.

Finally, we in the appendix derive the MNE's profits under favoritism:

$$
\pi_{m}^{\circledast}=\pi_{m}^{*}=\hat{\pi}_{m}(1-2 \gamma)^{\frac{1}{1-\alpha}}
$$

Equation (28) suggests that favoritism does not entail an extra loss in IJV performance. That is, for $s^{\circledast}<1$, the MNE's profits are identical to its profits with $\delta=0$ (equation (19)). We state this as our final proposition.

Proposition 5 As long as the IJV remains feasible $\left(s^{\circledast}<1\right)$, an increase in judicial favoritism $\delta$ does not reduce the performance of the IJV.

The proposition suggests that, for a given level of contract enforcement, an IJV can effectively neutralize the incentive distortion created by judicial favoritism by increasing the ownership share of the multinational firm in the IJV contract.

\section{Discussion}

Our model provides a tractable framework for analyzing how contract enforcement and judicial favoritism affect the ownership structure and performance of an IJV. The model makes several predictions that could be tested empirically with a micro-level dataset on IJVs that spans multiple countries.

An important prediction of our model is that weaker contract enforcement induces IJV parties to raise the ownership share of the minority partner in the joint venture, thus moving ownership shares towards a 50-50 equity distribution. This is in line with the empirical observation that ownership is clustered around 50-50 equity allocations in many joint ventures around the world (Bai et al., 2004; Hauswald and Hege, 2009; Moskalev and Swensen, 2007). Furthermore, it can help explain the empirical finding that IJVs with shared management arrangements tend to perform better than those with a dominant parent in many developing countries (Beamish, 1985; Beamish and Choi, 
2004). Our theoretical explanation for this phenomenon, however, differs from previous studies. The established argument has been that IJV parties adopt 50-50 ownership to prevent the majority partner from ex post using its control rights to unilaterally extract rents from the joint venture (Bai et al., 2004; Hauswald and Hege, 2009; Wang and Zhu, 2005). In our model, the majority partner's power to ex post expropriate rents from the minority partner is driven by the institutional environment and not by control rights. Our alternative explanation could be tested empirically by investigating if 50-50 equity clustering becomes more prevalent as contract enforcement weakens.

A second prediction is that judicial favoritism towards local firms increases the ownership share of the MNE in the IJV, in order to neutralize the local firm's institution-based ability to ex post extract IJV rents from the multinational firm. This prediction is in line with Henisz's (2000) empirical finding that, in countries with weak contract enforcement, political hazards induce MNEs to become a majority IJV partner instead of a minority IJV partner. Indeed, Henisz (2000) attributes this result to the fact that political hazards strengthen the local partner's ability to manipulate the political system and ex post expropriate IJV rents from the MNE. Nonetheless, more empirical work can be done to isolate the effect of judicial favoritism on the IJV's equity distribution.

A third prediction is that judicial favoritism does not necessarily affect the performance of the IJV negatively (except at boundary conditions). Specifically, our model suggests that IJV parties can neutralize the negative performance effect of a predictable judicial bias in favor of local firms by increasing the MNE's ownership share. The reason why we obtain this result is because a rise in judicial favoritism does not reduce the precision of adjudication in our model. Both IJV parties ex ante have perfect knowledge what the cost is of conducting ex post rent-seeking actions. In reality, environments with weak contracting institutions may embed significant arbitrariness which make the cost of ex post rent-seeking actions highly uncertain. A court's ruling, for example, is often subject to a judge's capriciousness and idiosyncratic views which are not necessarily known to IJV parties when signing the contract (Gennaioli, 2012). The inherent ambiguity that surrounds corrupt transactions further exacerbates this uncertainty (Rodriguez et al., 2005; Wei, 1997). If judicial favoritism goes hand in hand with an increase in enforcement risk, this can create an additional channel (not present in our model) that reduces the performance of an IJV (Gennaioli, 2012).

There are a number of other assumptions behind our model that deserve further discussion. 
First, our model assumes that contractual disputes among IJV partners are litigated in the host country's court. This is not necessarily the case. As Casella (1996), Dixit (2011) and Mattli (2001) have highlighted, IJV parties could try to circumvent problems related to weak contractual institutions by stipulating in their contract that any disputes will be resolved in a foreign court or in an international arbitration tribunal. With the exception of perhaps the largest IJVs, however, most IJV disputes continue to depend on host country courts for two reasons. First, international arbitration tends to be very costly, which makes it unattractive for disputes that do not involve a huge amount of money (Casella, 1996). Second, unless both IJV parties have significant immobile assets abroad, foreign courts and arbitration tribunals may have a difficult time enforcing their ruling in the IJV's host country. ${ }^{11}$ Indeed, IJV parties in that case will still need to rely on local officials to enforce foreign rulings (Moenius and Berkowitz, 2011).

For IJVs that have the credible option of settling their disputes in a foreign court or international arbitration tribunal, our model can provide insights into the optimal ownership structure of the IJV. In that case, we simply need to replace the $\gamma_{i}$ parameters of the host country by those of the foreign country or international arbitration tribunal. In future work, it seems worthwhile investigating which factors drive an IJV's decision to export its dispute settlements to a foreign court or international arbitration tribunal.

Second, our analysis has been based on the assumption that the MNE has the full ex ante bargaining power of proposing a take-it-or-leave-it revenue sharing contract to the local firm. It may be asked to what extent the results are driven by this particular assumption about the parties' ex ante bargaining positions. It turns out that our results are not sensitive to this assumption. As Dasgupta and Tao (1998) have also shown, the lump-sum transfer in the IJV contract implies that it is optimal for any party that proposes the IJV contract to choose the ownership structure that maximizes the joint surplus of the IJV, given each party's respective participation constraints. Indeed, the propositions and corollaries would be unaltered if the local firm had the full power to offer a take-it-or-leave-it contract to the multinational firm or if each party had a probability of $50 \%$ of proposing a take-it-or-leave it offer. ${ }^{12}$

\footnotetext{
${ }^{11}$ Isaacson (2002) provides evidence that domestic courts in Russia, Indonesia and Pakistan are frequently tempted to put aside foreign arbitration awards to protect domestic companies.

${ }^{12}$ This does not mean that the ex ante bargaining position is unimportant in an IJV: it determines the distribution
} 
Third, our predictions do not depend on the IJV's constant-returns-to-scale production technology. In Appendix A.2, we present a generalized model in which the IJV's production function can take on different degrees of returns to scale. We show that our propositions and corollaries continue to hold in the generalized model.

Finally, our results do critically depend on our assumptions related to the cost of taking ex post rent-seeking actions. Particularly, our prediction that a decrease in contract enforcement disproportionately weaken the incentives of the minority IJV partner is because, in the rent-seeking contest, both IJV parties need to increase their spending on rent-seeking actions equally, but the minority partner only receives a smaller share of the benefits of these rent-seeking actions. These results do not necessarily hold if the majority partner also faces higher rent-seeking costs, or if rent-seeking costs are a function of a party's revenue share. In the real world, nonetheless, it is unclear why a party's ability to create litigation arguments or to bribe court officials would depend on revenue share and not on the total resources spent.

\section{Conclusion}

The question at the heart of this paper is how contracting institutions affect the optimal ownership structure in an IJV. To address this, we have set up a simple IJV model where both the MNE and its local partner can ex post take costly rent-seeking actions to increase their ex ante agreed upon revenue share. Our novel approach for modeling contracting institutions has allowed us to in a simple and transparent fashion determine key channels through which contract enforcement and judicial favoritism affects the optimal ownership structure in IJVs. Our model has allowed us to identify new hypotheses relating the level of contract enforcement and the level of judicial favoritism with the IJV's feasibility, performance and optimal ownership structure. This opens the door for new empirical work on this topic.

of residual profits between the IJV partners. 


\section{A Appendix}

\section{A.1 Imperfect contract enforcement and judicial favoritism}

In this appendix, we solve the IJV model with both imperfect contract enforcement and judicial favoritism through backward induction.

Period 3. For a given $(s, t, m, d)$, parties solve

$$
\begin{gathered}
\max _{r_{m}} \pi_{m}=\left(s-r_{d}+r_{m}\right) R-e^{\frac{r m}{\gamma-\delta}}-\rho m+t \\
\max _{r_{d}} \pi_{d}=\left(1-s+r_{d}-r_{m}\right) R-e^{\frac{r_{d}}{\gamma+\delta}}-\omega \cdot d-t
\end{gathered}
$$

The solution of these problems gives:

$$
\begin{aligned}
& r_{m}^{\circledast}=(\gamma-\delta)(\ln R+\ln (\gamma-\delta)) \\
& r_{d}^{\circledast}=(\gamma+\delta)(\ln R+\ln (\gamma+\delta)) .
\end{aligned}
$$

To simplify notation below, let

$$
\Delta(R)=r_{d}^{\circledast}-r_{m}^{\circledast}=2 \delta \ln R+(\gamma+\delta) \ln (\gamma+\delta)-(\gamma-\delta) \ln (\gamma-\delta) .
$$

Then, the MNE's ex post revenue share is

$$
v=s-\Delta(R)
$$

Period 2. For a given $(s, t)$, parties choose inputs $m$ and $d$. By inserting (A-3) and (A-4) into (A-1) and (A-2), their maximization problems can be reduced to:

$$
\begin{gathered}
\max _{m} \pi_{m}=(s-\Delta(R)-\gamma+\delta) R-\rho m+t \\
\max _{d} \pi_{d}=(1-s+\Delta(R)-\gamma-\delta) R-\omega d-t,
\end{gathered}
$$

where $R$ is a shortcut for $R(m, d)$, which is given by (3). 
Next, we will demonstrate that when $\alpha \in(0,1 / 2)$ for any fixed $s$, there exists a unique optimal $m^{\circledast}$ and $d^{\circledast}$, and, therefore a unique $v(s)$. This permits us to use $v$ as the choice variable in period 1, which will make our calculations easier. Due to parties' optimization,

$$
\frac{\partial \pi_{m}}{\partial m}=0 \text { and } \frac{\partial \pi_{d}}{\partial d}=0
$$

The uniqueness of $m^{\circledast}$ and $d^{\circledast}$ is then assured if:

$$
\frac{\partial^{2} \pi_{m}}{[\partial m]^{2}} \leq 0 \text { and } \frac{\partial^{2} \pi_{d}}{[\partial d]^{2}} \leq 0
$$

If we solve problems (A-7) and (A-8),

$$
\begin{gathered}
\frac{\partial \pi_{m}}{\partial m}=(s-\Delta(R)-\gamma-\delta) \frac{\alpha \eta R}{m}-\rho=0 \\
\frac{\partial \pi_{d}}{\partial d}=(1-s+\Delta(R)-\gamma+\delta) \frac{\alpha(1-\eta) R}{d}-\omega=0 .
\end{gathered}
$$

where we use (3) and (A-5) to derive that

$$
\frac{\partial R}{\partial m}=\frac{\alpha \eta R}{m} \text { and } \frac{\partial R}{\partial d}=\frac{\alpha(1-\eta) R}{d} \text { and } \frac{d \Delta(R)}{d R}=\frac{2 \delta}{R} .
$$

We can then use (A-9) and(A-10) to determine that $m^{\circledast}$ and $d^{\circledast}$ are unique as long as $\alpha \leq 1 / 2$. Specifically, if $\alpha \leq 1 / 2$,

$$
\frac{\partial^{2} \pi_{m}}{[\partial m]^{2}}=\frac{\alpha \eta R}{m^{2}}((s-\Delta(R)-\gamma-\delta)(\alpha \eta-1)-2 \delta \alpha \eta) \leq 0
$$

and

$$
\frac{\partial^{2} \pi_{d}}{[\partial d]^{2}}=\frac{\alpha(1-\eta) R}{d^{2}}((1-s+\Delta(R)-\gamma-\delta)(\alpha(1-\eta)-1)+2 \delta(2 \alpha(1-\eta)-1)) \leq 0
$$

where we infer from (A-9) that $s-\Delta(R)-\gamma-\delta \geq 0$ and from (A-8) that $1-s+\Delta(R)-\gamma-\delta \geq 0$.

Uniqueness of $m^{\circledast}$ and $d^{\circledast}$ then permits us to use $v$ as an independent variable, and find $s=s(v)$, 
$m(v), d(v)$ and $R(v)$. If we combine (A-6), (A-9) and (A-10),

$$
\frac{m}{\eta}=\frac{(v-\gamma-\delta) R \alpha}{\rho}
$$

and

$$
\frac{d}{1-\eta}=\frac{(1-v-\gamma+\delta) R \alpha}{\omega}
$$

We can then insert (A-11) and ((A-12)) into (3) to express $R$ as a function of $v$ :

$$
R(v)=\lambda\left[\alpha\left(\frac{v-\gamma-\delta}{\rho}\right)^{\eta}\left(\frac{1-v-\gamma+\delta}{\omega}\right)^{1-\eta}\right]^{\frac{\alpha}{1-\alpha}}
$$

Period 1. In period 1 , the MNE solves for the optimal contract $(s, t)$. Since there is a unique $v^{\circledast}$ corresponding to $s^{\circledast}$, we can use $v$ as the choice variable. We can express the MNE's maximization problem as:

$$
\max _{v, t} \pi_{m}=(v-\gamma+\delta) R(v)-\rho m(v)+t
$$

subject to

$$
\pi_{d}=(1-v-\gamma-\delta) R(v)-\omega d(v)-t \geq 0
$$

which simplifies to:

$$
\max _{v} \pi_{m}=((1-\alpha \eta)(1-2 \gamma)-\alpha(1-v-\gamma+\delta)) R(v)
$$

We can then solve (A-14) to obtain $v^{\circledast}$ :

$$
v^{\circledast}=\hat{s}-\gamma \frac{1-2 \psi}{2 \eta-1}+\delta
$$

where $\hat{s}$ is given by (8). From (A-6), we can obtain the corresponding $s^{\circledast}$ as

$$
s^{\circledast}=v^{\circledast}+\Delta\left(R^{\circledast}\right)
$$


Finally, we can insert (A-15) into (A-14) and combine with (19) to derive the MNE's profits:

$$
\pi_{m}^{\circledast}=\pi_{m}^{*}=\hat{\pi}_{m}(1-2 \gamma)^{\frac{1}{1-\alpha}}
$$

\section{A.2 IJV production technology}

In this appendix, we verify that our main results continue to hold when the production technology features increasing or decreasing returns to scale. Suppose that the IJV produces final goods $y$ using the following production function:

$$
y=\left[\left(\frac{m}{\eta}\right)^{\eta}\left(\frac{d}{1-\eta}\right)^{1-\eta}\right]^{\epsilon}
$$

where $\eta \in[0,1]$ characterizes the intensity of foreign inputs in production, and $\epsilon$ captures returns to scale. The production technology features increasing returns if $\epsilon>1$, constant returns if $\epsilon=1$ and decreasing returns if $\epsilon<1$.

We first analyze the benchmark case of perfect contract enforcement. Using the same steps as in the paper, it is straightforward to derive the multinational firm's optimal ownership share:

$$
\tilde{s}=\left\{\begin{array}{cc}
1 / 2 & \text { if } \eta=1 / 2 \\
\frac{\eta-\tilde{\Psi}}{2 \eta-1} & \text { if } \eta \neq 1 / 2
\end{array}\right.
$$

where

$$
\tilde{\Psi}=\tilde{\alpha} \eta(1-\eta)+\sqrt{\eta(1-\eta)(1-\tilde{\alpha} \eta)(1-\tilde{\alpha}+\tilde{\alpha} \eta)}
$$

and

$$
\tilde{\alpha}=\alpha \epsilon .
$$

The multinational firm's profits then equal:

$$
\tilde{\pi}_{m}=\lambda^{\frac{1-\alpha}{1-\tilde{\alpha}}} \tilde{\Omega},
$$


where

$$
\tilde{\Omega}=\frac{(1-\tilde{\alpha}(1-\tilde{\Psi}))}{\left(\frac{2 \eta-1}{\tilde{\alpha}}\left(\frac{\rho}{\eta-\tilde{\Psi}}\right)^{\eta}\left(\frac{\omega}{\eta+\tilde{\Psi}-1}\right)^{1-\eta}\right)^{\frac{\tilde{\alpha}}{1-\tilde{\alpha}}}} .
$$

We next analyze the case with imperfect contract enforcement and judicial favoritism. Using the same analytical steps as in Appendix A, we can derive the multinational firm's optimal ex post revenue share to be:

$$
v^{\circledast}=\tilde{s}-\gamma \frac{1-2 \tilde{\psi}}{2 \eta-1}+\delta
$$

where $\tilde{s}$ is given by (B-1) and $\tilde{\Psi}$ is given by (B-2). Equation (B-5) suggests that the degree of returns to scale $\epsilon$ has the same effect on the optimal ownership structure as the elasticity of demand parameter $\alpha$. From equation (B-5), it is straightforward to verify that our Propositions 1 and 3 hold regardless of our assumptions on the degree of returns to scale.

If the multinational firm adopts $v^{\circledast}$, he obtains the following profits:

$$
\pi_{m}^{\circledast}=\tilde{\pi}_{m}(1-2 \gamma)^{\frac{1}{1-\tilde{\alpha}}}
$$

where $\tilde{\pi}_{m}$ is given by (B-4) and $\tilde{\alpha}$ is given by (B-3). From (B-6), it is clear that Propositions 2,4 and 5 hold regardless of the degree of returns to scale. Furthermore, we can expand Corollary 1 by indicating that the negative effect of contractual frictions on IJV performance is magnified by both an increases in the elasticity of demand $(\alpha)$ and an increase in the degree of returns to scale $(\epsilon)$. 


\section{References}

[1] Acemoglu, D., Antras, P., Helpman, E., 2007. Contracts and technology adoption. The American Economic Review 97, 916-943.

[2] Acemoglu, D., Johnson, S. 2005. Unbundling institutions. Journal of Political Economy 113, 949-995.

[3] Antràs, P., Helpman, E., 2008. Contractual frictions and global sourcing, in: Helpman, E., Marin, D., Verdier, T. (Eds.), The Organization of Firms in a Global Economy. Harvard University Press, Cambridge, pp. 9-54.

[4] Bai, C., Tao, Z., Wu, C., 2004. Revenue sharing and control rights in team production: theories and evidence from joint ventures. Rand Journal of Economics 35, 277-305.

[5] Beamish, P., 1985. The characteristics of joint ventures in developed and developing countries. Columbia Journal of World Business, 20, 13-19.

[6] Beamish, P., Choi, C. 2004. Split management control and international joint venture performance. Journal of International Business Studies, 35, 201-215.

[7] Beamish, P., Lupton, N. 2009. Managing joint ventures. Academy of Management Perspectives $23,75-94$.

[8] Bhattacharyya, S., Lafontaine, F., 1995. Double-sided moral hazard and the nature of share contracts. The RAND Journal of Economics 26, 761-781.

[9] Bond, P. 2009. Contracting in the presence of judicial agency. The B.E. Journal of Theoretical Economics 9, article 36 .

[10] Casella, A., 1996. On market integration and the development of institutions: the case of international commercial arbitration. European Economic Review 40, 155-186.

[11] Cuervo-Cazurra, A., Maloney, M., Manrakhan, S., 2007. Causes of the difficulties in internationalization. Journal of International Business Studies 38, 709-725. 
[12] Dasgupta, S., Tao, Z., 1998. Contractual incompleteness and the optimality of equity joint ventures. Journal of Economic Behavior and Organization 37, 391-413.

[13] Dixit, A., 2011. International trade, foreign direct investment, and security. Annual Reviews of Economics 3, 191-213.

[14] Gennaioli, N., 2012. Optimal contracts with enforcement risk. Journal of the European Economic Association, forthcoming.

[15] Gennaioli, N., Perotti, E., 2012. Standardized enforcement: access to justice vs contractual innovation. Mimeo.

[16] Glaeser, E., Shleifer, A., 2002. Legal origins. Quarterly Journal of Economics 117, 1193-1230.

[17] Hauswald, R., Hege, U., 2009. Ownership and control in joint ventures. Mimeo.

[18] Hay, J., Shleifer, A., Vishny, R. 1996. Toward a theory of legal reform. European Economic Review 40, 559-567.

[19] Henisz, W., 2000. The institiutional environment for multinational investment. The Journal of Law, Economics and Organization 16, 334-364.

[20] Henisz, W., Williamson, O., 1999. Comparative economic organization — within and between borders. Business and Politics 1, 261-277.

[21] Hennart, J., 1988. A transaction cost theory of equity joint ventures. Strategic Management Journal 9, 361374 .

[22] Inkpen, A., Beamish, P., 1997. Knowledge, bargaining power, and the instability of international joint ventures. Academy of Management Review 22, 177203.

[23] Isaacson, W., 2002. Enforcement difficulties are increasing. National Law Journal 25, 55.

[24] Javorcik, B., Wei, S.-J., 2009. Corruption and cross-border investment in emerging markets. Journal of International Money and Finance 28, 605-624. 
[25] Khanna, T., Palepu, K.,Sinha, J., 2005. Strategies that fit emerging markets. Harvard Business Review, 63-76.

[26] Luo, Y., 2002. Capability exploitation and building in a foreign market: implications for multinational enterprises. Organizational Studies 13, 48-63.

[27] Mattli, W. 2001. Private justice in a global economy: from litigation to arbitration. International Organization 55, pp. 919-947.

[28] Meyer, K., Estrin, S., Bhaumik, S., Peng, M., 2009. Institutions, resources, and entry strategies in emerging economies. Strategic Management Journal 30, 61-80.

[29] Moskalev, S., Swensen, B., 2007. Joint ventures around the global from 1990-2000: Forms, types, industries, countries and ownership patterns. Review of Financial Economics 16, 29-67.

[30] Moenius, J., Berkowitz, D., 2011. Law, trade, and development. Journal of Development Economics $96,451-460$.

[31] Mui, V.-L., 1999. Contracting in the shadow of a corrupt court. Journal of Institutional and Theoretical Economics 155, 249-283.

[32] North, D., 1990. Institutions, Institutional Change, and Economic Performance. Cambridge University Press, New York.

[33] Rodriguez, P., Uhlenbruck, K., Eden, L., 2005. Government corruption and the entry strategy of multinationals. The Academy of Management Review 30, 383-396.

[34] Steensma, H., Lyles, M., 2000. Explaining IJV survivial in a transitional economy through social exchange and knowledge-based perspectives. Strategic Management Journal 21, 831851.

[35] Wang, S., Zhu, T., 2005. Control allocation, revenue sharing, and joint ownership. International Economic Review 46, 895-915.

[36] Wei, S.-J., 1997. Why is corruption so much more taxing than a tax? National Bureau of Economic Research Working Paper No. 6255. 


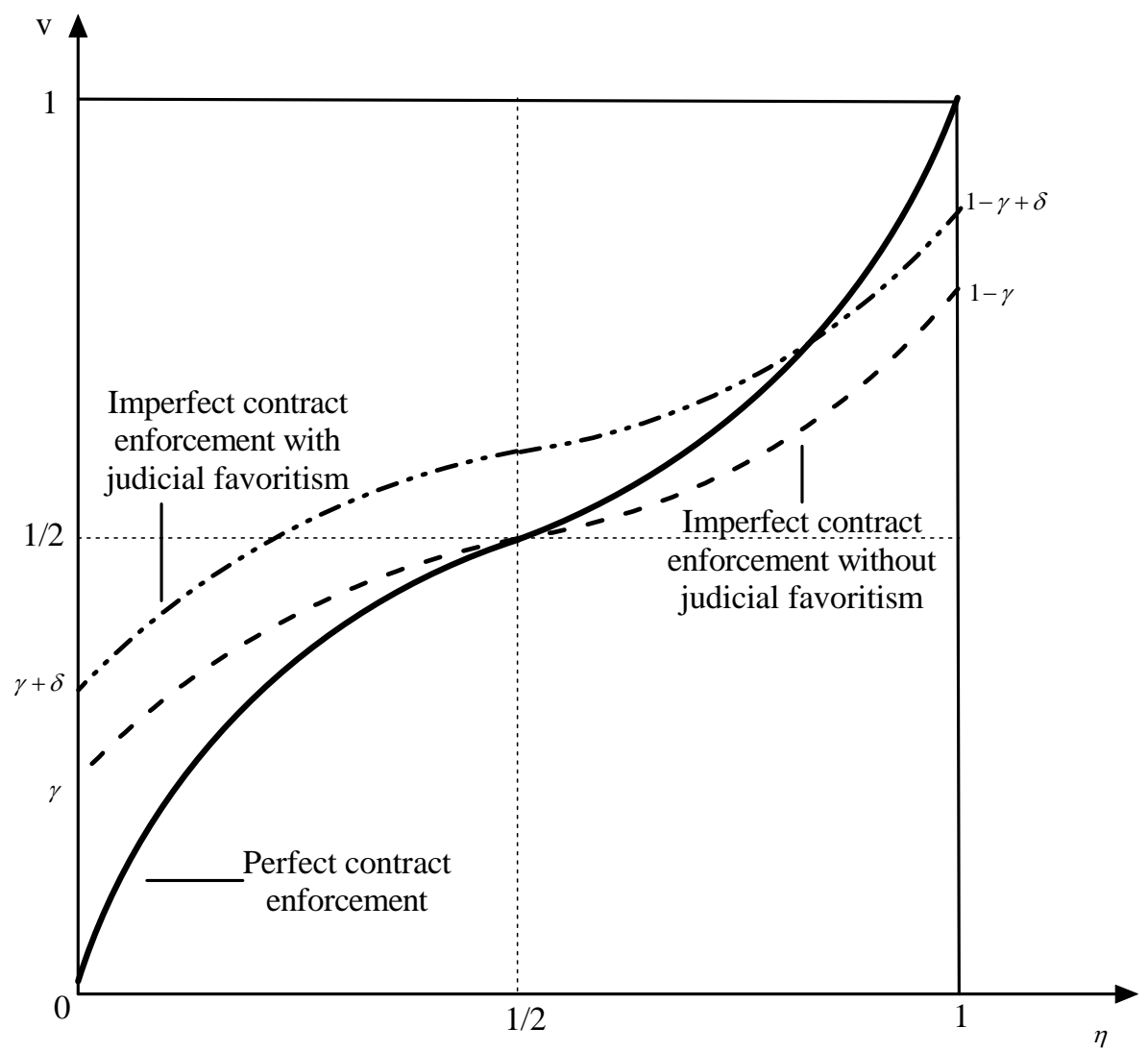

Figure 1: Optimal ex post revenue distribution in an IJV 